\title{
Preventative role of criminal law for traffic safety
}

\author{
Nataliya Gutorova ${ }^{1}$ and Oleksandra Rudnyeva $^{2}$ \\ ${ }^{1}$ Yaroslav Mudry National Law University, Kharkiv, Ukraine \\ ${ }^{2}$ International Legal Council LEGITEAM, Kiev, Ukraine
}

\begin{abstract}
The purpose of the article is to raise awareness of and stimulate serious discussion about the necessity to improve the preventative role of criminal law in the field of traffic safety by adjusting criminal liability for crimes in this area, and determining the proportional amount of force that may be used by the police in order to stop the vehicle and detain the offender.

Key words: preventative role of criminal law, criminal liability, exemption of criminal liability, traffic safety, extent of justified damage.
\end{abstract}

\section{Introduction}

The modern world cannot exist without transport. However, the use of vehicles, in states and societies that do not pay sufficient attention to traffic safety, poses a significant threat to the lives of people. According to the Global status report on road safety 2018 of the World Health Organization (WHO), the number of road traffic deaths continues to increase reaching 1.35 million in 2016. Road traffic injury is now the leading cause of death for children and young adults aged 5-29 years, signaling a need for a shift in the current child health agenda, which has largely neglected road safety. It is the eighth leading cause of death for all age groups surpassing HIV/AIDS, tuberculosis and diarrheal diseases. Experts came to these conclusions after analyzing the situation in 175 countries [1].

1.35 million cases of death a year means that nearly 3,700 people die on the world's roads every day; every 24 seconds someone dies. Dr. Tedros Adhanom Ghebreyesus, DirectorGeneral of WHO in the Foreword to the Report underlined that tens of millions more are injured or disabled every year resulting in life-altering injuries with long-lasting effects. These losses take a huge toll on families and communities. The cost of emergency response, health care and human grief is immense [1].

European countries provide comparatively safer conditions for traffic users. For the 51 European countries included into the Report the average rate of road traffic deaths per 100,000 of population in 2016 were 9.3. The lowest rate - 2.7 - belongs to Norway and Switzerland, the highest - 18.1 - to Tajikistan. Whereas Latvia's was 9.3 - equal to the average European rate, Ukraine has a rate of 13.7. Unfortunately, along with Azerbaijan, it has the highest in Europe rate of pedestrian fatalities -42 - and thus joined the group of countries that are the worst in terms of this indicator, namely Kyrgyzstan -40 and Belorussia -41 .

According to the official statistics of the Prosecutor General's Office of Ukraine [2] there were 11157 crimes registered in 2016 and 10011 in 2017 stipulated in Art. 286 of the Criminal Code of Ukraine [3]. The number of victims in 2016 with at least moderate bodily injuries was 12833, including 2417 who died. In 2017 the number of victims was 12088, of which 2015 persons died. 
Moreover, the statistics shows the severity of the issue as the number of traffic fatalities and injuries in Ukraine in 2015-2017 significantly exceeds the number of victims of military conflict (including civilians) in the East of the country.

Attention should be paid to the difference in traffic fatality data provided by the three state agencies in 2016. The Prosecutor General's Office of Ukraine reported about 2417, State Statistics Service of Ukraine - about 4687 and the WHO in its Global status report on road safety 2018, estimated 6089 road traffic fatalities. Such a difference in figures (more than in 2.5 times) is due to the fact that the Prosecutor General's Office of Ukraine makes relevant information about the victims of accidents in the statistical reporting immediately after the crime without counting the number of persons whose death occurred later in the hospitals. There are also some questions surrounding the reliability of the statistics. The example of Ukraine is not unique. Similar irregularities and discrepancies exist in other countries. Therefore, the development of measures to combat mortality and injury resulting from traffic accidents should be based on statistical information provided by WHO experts.

Strengthening legislation to mitigate key risk factors is recognized by the majority of governments as an important strategy to improve road safety [1]. We believe that Criminal law plays an important role in implementation of these tasks as it has the most severe tools in terms of punitive treatment of the offender, and should apply to acts that have led to a significant threat to the life or health of a person.

Criminal science mainly studies the liability for violating traffic safety rules or operating a vehicle in such a way as to cause damage to life or health of a person. Such acts are undoubtedly recognized as crimes and for their commission severe punishments are stipulated, especially in case of homicidal acts. The measures to ensure the preventive role of criminal law for traffic safety have been studied insufficiently.

Aim. The purpose of the article is to raise awareness of and stimulate serious discussion about the necessity to improve the preventative role of criminal law in the field of traffic safety by adjusting criminal liability for crimes in this area, and determining the proportional amount of force that may be used by the police in order to stop the vehicle and detain the offender.

\section{Materials and methods}

This study was conducted in 2018 and is based on the national regulatory acts on traffic safety, the European Convention for the Protection of Human Rights and Fundamental Freedoms, case law of European Court of Human Rights (ECHR), WHO Status Report on Road Safety 2018, criminal legislation of selected countries such as Germany, Ukraine, Poland, Latvia, the Ukrainian police and General Prosecutor's Office data on the criminal liability of those who committed crimes in the field of traffic safety and the Ukrainian Ministry of Health's statistics on traffic fatalities and injuries. Totally 34 laws and papers, 123 court judgments, 16 traffic incidents reports were analyzed.

Dialectical, comparative, analytic, synthetic and system analyses research methods were used, also for interpretation purposes.

\section{Results and discussion}

The effectiveness of the measures to ensure the protection of transport security by criminal law can be understood through the analysis of three relatively independent but closely related issues: 1) the establishment and application of criminal liability for offenses that pose a serious threat to traffic safety; 2) the liability for violating the traffic safety or vehicle driving rules, resulting in causing damage to the life or health of a person; 3 ) the proper regulation of 
circumstances surrounding a crime, in order to ensure the right of law enforcement officers to stop a vehicle that poses a real threat to the life or health of a human.

Drink-driving and drug-driving are at the top of the WHO reported list, among 9 types of key risk factors for the lives and health of drivers and pedestrians. It is estimated that between $5 \%$ and $35 \%$ of all road deaths are reported as alcohol-related. Driving after drinking alcohol significantly increases the risk of a crash and the severity of that crash. This conclusion is fully confirmed by the analysis of statistical data from the General Prosecutor's Office of Ukraine over the last 5 years. Yes, if among the registered crimes stipulated in Art. 286 of the Criminal Code of Ukraine for the period from 2013 to 2017, the number of crimes committed in the state of intoxication was $5.7 \%$, among these crimes, up to $10.1 \%$ persons died.

Nevertheless a comparison of the criminal laws of Ukraine, Germany, Poland and Latvia shows that the principal difference lies in the identification and punishment for offences that did not lead to actual damage, but were still dangerous.

In Poland, drink or drug driving has been already penalized in article 178a of the Criminal Code of the Republic of Poland [4]. In par.1 of Section 262 of the Criminal Law of The Republic of Latvia it states the criminal liability for any person who operates a vehicle if he or she does not have a driver's license (the driver's license has not been obtained according to the procedures or has been taken away) and if the driver is under the influence of alcohol, or narcotic, psychotropic, toxic or other intoxicating substances [5].

Germany established a completely different determination of liability for violation of traffic safety. In Section 316 "Driving while under the influence of drink or drugs" of the Criminal Code of Germany liability is established with no conditions attached. Moreover, the list of circumstances which causes criminal liability is extensive and forms a solid preventive foundation, where even the potential for danger to traffic safety is considered a crime (Section $315 c$ "Endangering road traffic") [6].

In Ukraine the violation of traffic safety rules and driving vehicles rules is considered to be an administrative offence, and, based on the Code of Administrative Offences of Ukraine, the following types of penalties are imposed, such as fines and, in some cases, deprivation of the right to drive vehicles. Just very recently, at the very end of 2018 the parliament of Ukraine voted to criminalize drink and drug driving, but this legislation has not been enforced yet [7].

In the meantime, beyond the statistics, incidents involving drunk driving occur daily in Ukraine. It must be assumed that the fact that drunk driving is not considered a serious crime partly determined the behavior of this person. In view of this, the criminalization of such offences is well grounded. In the case of the effective application of the criminal law, it can positively influence traffic safety.

The main question is how to achieve a relevant punishment for such an offense, with the goal of preventing traffic crashes. The Criminal Code of the Republic of Poland for this crime in Art.178a established punishment in the form of a fine, restriction of liberty or deprivation of liberty, and - in the case of a second offence-deprivation of liberty from three months to two years. The Criminal Law of the Republic of Latvia established punishment as the deprivation of liberty for a period of up to one year, or temporary deprivation of liberty, or community service, with the removal of the driver's license for a period of up to five years. Pursuant to German Criminal Code such a crime should be liable to imprisonment not exceeding one year or a fine.

Ukraine has established only a fine and the removal of a driving license, and no restrain of labour rights in the form of public work or imprisonment, so it is softer in comparison to the law of the Republic of Poland, the Republic of Latvia and the Federal Republic of Germany. To determine the right type and weight of punishment for drink and drug driving it is necessary to consider that "these policies need to be evaluated at two distinct levels. Firstly, 
are they effective in producing at the lowest cost the desired outcome of safer driving and less incidents? Secondly, are they defensible in terms of sentencing principles of proportionality and consistency," [8] according to John Williams.

When determining the punishment for violating the rules of traffic safety, it is not easy to find the balance between severity, which should be related to the potential or real damage to people's life and health, and the often-positive character of the offender. Alwin van Dijk and Hein Wolswijk had underlined that "Criminal traffic offences are set apart from conventional criminal offences in that they are generally not committed by hardened criminals. Many serious traffic accidents are caused by fairly ordinary people who - at least up to that moment - were perceived as well-meaning human beings. Once the criminal law has set its sights on these ordinary people, they may face penalties that are otherwise reserved for the most heinous crimes." [9]

Fines and the deprivation of the right to drive a vehicle as punishment for drink and drug driving are not, on their own, always effective deterrents. This is especially true in cases of repeated offenses committed by people who are already deprived of their driving license.

A penalty in the form of a fine is, in reality, often settled at the expense of the offender's family members, the preventive role of the criminal punishment is not actually achieved. Obviously, the possibility to be deprived of liberty, even for a short-term, or to perform community work can be more effective for alcohol and drug users. This is especially true for drivers who count on the financial support of parents or other family members.

The next traffic safety offence, which WHO experts fully justify as a key risk factor, is speeding. It is extremely dangerous, most of all for pedestrians.

So, for example, a terrible traffic incident took place in downtown Kharkiv on the 18th of October 2017. A "Lexus" careered onto the sidewalk after a crash: 6 people were killed, 5 were gravely injured. Experts have identified that one of the participants of the accident, the driver of "Lexus", 18 years old Olena Z., drove into the centre of the city at the speed of 106 $\mathrm{km} / \mathrm{h}[10]$.

According to the WHO Report "Even small reductions in speed affect fatal and serious crash risk; 5\% reduction in average speed can reduce the number of fatalities by 30\%" [1]. The relationship between the violation of speed limits on urban roads and pedestrian injuries has been calculated by WHO experts: "for pedestrians hit by car fronts, the death risk rises rapidly (4.5 times from $50 \mathrm{~km} / \mathrm{h}$ to $65 \mathrm{~km} / \mathrm{h}$ )." The cause-effect relationship between violation of speed limits and pedestrian fatalities is also understood by the experts. Despite that Ukraine has highest level of pedestrian fatality (42\%), the level of enforcement of the national speed limit law is the lowest (3 out of 10) $[1,11]$.

These statistics show the necessity to penalize violation of speed limit. At the same time, criminal liability can be introduced only if all other legal measures have been exhausted $[12,13]$.

Such measures should be effective, and can replace criminal liability. To achieve that goal, a sufficient number of technical devices for the automatic detection of such offenses should be installed on the roads. This will create a strong barrier against corruption and allow a high level of inevitability of liability. Under such conditions, administrative punishment for speeding in the form of a fine, and deprivation of the right to drive a vehicle, will be quite sufficient.

It should also be considered that the use of criminal liability requires significant funds from taxpayers that could be more effectively used to implement an effective system to automatically apply an administrative penalty to offenders. In 1968 Nobel Laureateeconomist Gary S. Becker in his work "Crime and Punishment: The Economic Approach" said that in counteracting crime, "optimal" decisions are interpreted to mean decisions that 
minimize the social loss in income from offenses" [14]. This theory has been confirmed and further developed in modern scientific research [15].

Turning back to Olena Z . case, the question arose - was everything done to avoid the tragedy? An eighteen and half years old adolescent girl with no fixed income, driving a luxury vehicle Lexus RX350 with already six recorded violations of the traffic rules and a fine paid by her parents, - all these factors classify her to the dangerous and/or risky group of drivers.

Also, she gained her driving experience at a time - 2015 - when the state had practically stopped controlling the speed on the roads. Devices used up to this time by the traffic police had not been certified, and new ones had not been purchased. For several years already, the introduction of automated detection of traffic violations has been prepared, but so far there is no control. That is why Olena $\mathrm{Z}$. case can be used as a tragic illustration of the need for a proper traffic safety national policy, including the appropriate technical and legal measures.

The study further tackles the aspect of criminal laws regulating the exemption from criminal liability circumstances where it applies to the establishment of cause and scope of involuntary harm caused by law enforcement officers during the execution of traffic safety arrangements. Analysis of this problem is important for the promotion of traffic safety, because any ambiguity in this matter may render the law enforcement totally helpless or cause grave violation of human rights.

The tragedy that stirred the entire community occurred in Kiev on 7 February 2016 around 3 a.m. A patrol car chased a BMW that flew across the city at almost $200 \mathrm{~km} / \mathrm{h}$ and would not pull over. After several warnings, the police officers used firearms, killing a 17 -year-old passenger. Charges of intentional homicide were brought against the officer who had made the fatal shot. Khatiya Dekanoidze, who was in charge of the National Police back then, made a statement at the trial, trying to prove that the officer in question had been legally correct to have shot his gun, but the AG representative and the court begged to disagree with it. The trial is still under way and the ruling is still pending. This accident became a milestone for the Ukrainian police after which patrolmen would not use firearms during their attempts to stop a vehicle, even when any such use appears to be absolutely warranted. Consequently, one can see obscenely expensive cars in the big cities of Ukraine racing down the night streets at around $200 \mathrm{~km} / \mathrm{h}$ or witness drag races while the police appear to be remarkably unable to pull the racers over.

So, one would reasonably ask whether or not the police are allowed to use firearms so as to stop a vehicle that poses a considerable danger to the public and cannot be stopped otherwise in each particular situation.

This matter needs to be resolved through the application of the principle of proportionality and the study of exemption from criminal liability circumstances. It is about the lawful acts envisaged by criminal and other laws which outwardly resemble crime. These deeds are actually considered to be for the good of the public or socially acceptable, so they shall not entail any criminal liability [16].

Certain exemption from criminal liability circumstances are defined in applicable laws (e.g., the absolute necessity, justifiable defence, apprehension of a criminal, etc.). However, the bulk of such circumstances can be found in special laws. For example, in Ukraine pursuant to Clause 7 Part 4 Article 46 of the Law "On National Police", a policeman may in exclusive cases use firearms to have the vehicle pull over by causing damage to the same, if the driver is acting in a manner jeopardizing life and health of the people and/or the police officer.

According to criminal laws, the police officer who uses firearms to stop a vehicle is found to be exercising his/her lawful powers [17] only if and when any such use is an absolute necessity. Refusal to cause harm shall not exempt one from liability for failure to perform or improper performance of one's duties. 
The grounds for the police officer to use firearms to stop a vehicle by causing damage to the latter comprise of the following factors: 1) the driver of a moving vehicle jeopardizes the life and health of the people and/or the police officer; 2) under the circumstances, the vehicle cannot be stopped in any other manner but by being damaged by firearms. Sub-clause 2 above means that previous actions failed to cause the vehicle stop, and life and health of the people are still jeopardized. The police officer may use firearms only after ordering the transgressor to stop unlawful activities and notifying the same of the intention to take the enforcement actions.

The European Convention for Human Rights and Fundamental Freedoms in the first paragraph of Article 2, specifies that everyone's right to life is protected by law, and in the second paragraph of Article 2 provides that death resulting from defending oneself or others, arresting a suspect or fugitive, or suppressing riots or insurrections, will not contravene the Article when the use of force involved is "no more than absolutely necessary".

In the ECHR decision in McCann and Others v. The United Kingdom, 27 September 27, 1995, considers that the exceptions delineated in paragraph 2 (art. 2-2) indicate that this provision (art. 2-2) extends to, but is not concerned exclusively with, intentional killing. The text of Article 2 (art. 2), read as a whole, demonstrates that paragraph 2 (art. 2-2) does not primarily define instances where it is permitted intentionally to kill an individual, but describes the situations where it is permitted to "use force" which may result, as an unintended outcome, in the deprivation of life. The use of force, however, must be no more than "absolutely necessary" for the achievement of one of the purposes set out in subparagraphs (a), (b) or (c) (art. 2-2-a, art. 2-2-b, art. 2-2-c) (see application no. 10044/82, Stewart v. the United Kingdom, 10 July 1984, Decisions and Reports 39, pp. 169-71) [18].

Judgment in the Case McKerr v. The United Kingdom [19], 4 May 2001, shows similar position, particularly in paragraph 200 of a Judgment in McCann and Others v. The United Kingdom provision (art. 2-2).

ECHR also approved situations where it is permitted to use force which might result in the deprivation of life in their Judgment Andronicou and Constantinou v. Cyprus [20], 09 October 1997, when the police used weapon to save the life of a woman who was kidnapped by her future husband and accidentally killed both. In certain circumstances, prevention of the loss of life, similar to the case Giuliani and Gaggio v. Italy [21] 25.08 2009, has to be properly planned and controlled by the state "taking into consideration not only the actions of the agents of the State who actually administer the force".

So, the Court accepts situations where it is permitted to use force which might result in the deprivation of life. In case where the police officer applies force based on the sincere conviction of the necessity of the response, the violation of the right to life may be justified, despite that later it can be proven as mistake.

The extent of permissible damage, subject to circumstances exempt from criminal liability, shall be determined by the extent of necessity (the need), maximum permissibility and reasonable sufficiency [16].

The necessity to cause damage exists if the police officer has no other options but to use firearms so as to stop a vehicle that jeopardizes life and health of the people.

Maximum permissible damage. Authorization to use firearms for the purpose of stopping a vehicle shall be based on the understanding that there may be human beings in the vehicle (or the driver alone) whose life and health may be harmed. This understanding is based on the assumption that a projectile from the weapons fired at the object that moves at a certain speed and along the trajectory that may be changed by the actions of the driver or by the properties of the road surface may penetrate the bodywork and hit a human body inside the vehicle. Any law, including the one considered herein, is made to the benefit of "the average man", a police 
officer - properly trained and skilled, whose psychic health is as sound as befits a normal human being. Without a doubt, that a highly professional sniper with skills honed in combat and with an extraordinary psychological fortitude, is capable of making exclusively clean shots without hitting a human being in the process. However, it does not mean that police academies should welcome exclusively such people. Now, therefore, maximum permissible damage caused by or resulting from the use of firearms by the police with the purpose of stopping the vehicle should be the loss of human lives inside the same vehicle.

The damage may be rated reasonably sufficient if, under specific circumstances, it served the objective of stopping the vehicle. Therefore, causing damage for any other purpose, such as apprehension of the driver or retaliation for the driver's refusal to obey the order of the police, etc., shall not be construed as damage lawfully caused.

\section{Conclusions}

1. Traffic safety is a responsibility of the state, which must be ensured through appropriate legal mechanisms.

2. The criminal law prevention can be achieved via: 1) the establishment and application of criminal liability for offenses that pose a serious threat to the life or health of a human; 2) clear definition of all situations, grounds and measures for the positive duty of the police to use force to prevent foreseeable loss of life which in certain circumstances might result in harm.

3. The matter of criminal liability for traffic violations or operation of a vehicle in a manner jeopardizing the life and health of a human being or causing risk of damage to other important social values shall be handled with clear understanding that: a) certain delinquent action may lead to highly dangerous consequences; b) the said action is pretty common; and c) cannot be effectively countered by other legal tools.

4. Criminal liability for drink and drug driving is essential due to its high risk to people's life and its widespread nature. For general and specific prevention purposes an appropriate basic punishment for a person who commits an offence for the first time should be a fine or restriction of liberty or a community service as its alternative. Additional obligatory punishments should be the deprivation of the driver's license for a period of up to five years. When the driver's license has been already taken away, the deprivation of liberty for a period from one to twelve months should be a basic punishment and the fine should be an additional punishment.

5. Speeding violations by drivers, although one of the key risk factors for traffic safety, do not require criminalization. It is quite possible to ensure an unavoidable administrative punishment for this act through the use of a large number of devices for automatic detection. Relevant technical solutions can significantly reduce the number of traffic offences.

6. The use of weapons by the policeman seeking to stop the vehicle by causing damage to the latter, if the driver of the same is acting in a manner that jeopardizes life and health of the people and/or the police officer, is the circumstance the circumstance that exempts from criminal liability and can be legally classified as the exercise of the official powers. The policeman may exercise the said powers in cases of extreme necessity. However, refusal to cause harm in such a manner shall not be construed to exempt the policeman from liability for failure to perform or improper performance of his official duties.

7. Lawful use of firearms for the purpose of stopping a vehicle is contingent on: 1) legal factors, such as provisions of applicable national laws (in Ukraine - Article 46 of the 
Law "On National Police") that are in line with the European Convention for Human Rights and Fundamental Freedoms (Clause "a" Part 2 Article 2); and 2) a set of factors: a) danger, potential or real, to life or health of the people and/or the policeman caused by or resulting from the breach of traffic regulations by the driver of a moving vehicle; and b) inability to stop the vehicle in this specific situation in a manner other than causing damage to the said vehicle by the use of firearms, providing however that any such use is absolutely necessary at this particular place and time and under the circumstances. The ECHR does not consider the use of force as violation of the right to live, if any such power is exercised by a law enforcement officer who is reasonably convinced that his/her action is right at this particular time and place but proves to be wrong at a later time.

8. The extent of justified damage caused by the policeman under the circumstances: 1) the necessity of any such action at this time and place that is based on every legal and actual evidence of the lawful use of firearms to stop the vehicle; 2) maximum permissible extent of damage that sufficiently justifies the use of firearms, which is to take the life of individuals inside the vehicle; and 3) damage caused with the sole purpose of stopping the vehicle.

\section{References}

[1] WHO Global status report on road safety (2018). Available at: https://www . who. int/violence_injury_prevention/road_safety_status/2018/en/

[2] Prosecutor General's Office of Ukraine. Available at: https : //www .gp.gov .ua/ua/ stst2011.html?dir_id=113281\&libid=100820\&c=edit\&_c=fo\#

[3] The Criminal Code of Ukraine. Available at: https://sherloc.unodc.org/cld/ document/ukr/2001/criminal_code_of_the_republic_of_ukraine_en.html

[4] Ustawa z dnia 6 czerwca 1997 r.Kodekskarny. Available at: http://prawo.sejm. gov.pl/isap.nsf/download.xsp/WDU19970880553/U/D19970553Lj ·pdf

[5] The Criminal Law of The Republic of Latvia. Available at: https://likumi. lv/ta/en/id/88966-the-criminal-law

[6] The Criminal Code of Germany. Available at: https://www.gesetze-iminternet.de/englisch_stgb/index.html

[7] Проект Закону про внесеннязмін до деякихзаконодавчихактівУк раїнищодоспрощеннядосудовогорозслідуванняокремихкатегорійкримін альнихправопорушень. Available at: http://w1.c1.rada.gov.ua/pls/ zweb2/webproc4_1?pf3511=63928

[8] Willis J. The Proper Role of Criminal Law in Road Safety. Available at: https:// aic.gov.au/sites/default/files/publications/proceedings/downloads/ 24-willis.pdf

[9] Criminal Liability for Serious Traffic Offences: Essays on Causing Death, Injury and Danger in Traffic, Eleven International Publishing (2015). Available at: https:// www.rug.nl/research/portal/files/28372541/Criminal_Liability_for_ Serious_Traffic_Offences_final.pdf

[10] ДТП у Харкові: експертизавстановила, наякійшвидкості “летіло” авто Зайцевої. Available at: https://espreso.tv/news/2018/12/20/dtp_u_ kharkovi_ekspertyza_vstanovyla_na_yakiy_shvydkosti_quotletiloquot_ avto_zaycevoyi

[11] A. Bukova-Zideluna, A. Villerusa, A. Lama. An overview on pedestrians involved in traffic accidents in Latvia: Years 2010-2014. SHS Web of Conferences 40, 01004 (2018) 
[12] Н.В. Генрих Предмет и метод уголовно-правового регулирования: история, теория и практика. М.,Норма; ИНФА-М, 237 (2011)

[13] О. Пащенко. Неможливістьборотьби з діянням за допомогоюінших (не кримінально-правових) засобів. National Law Journal: Theory and Practice. 6, 192-197 (2015)

[14] G.S. Becker. Crime and Punishment: An Economic Approach. Journal of Political Economy 76(2), 207 (1968)

[15] D. Husak D. Overcriminalization: The Limits of the Criminal Law. Oxford, Oxford University Press (2008)

[16] Ю.В.Баулін. Вибраніпрачі. Право, 103-321(2013)

[17] О.О. Дудоров, М.I. Хавронюк. Кримінальне право. K, Ваіте, 255 (2014)

[18] ECHR judgment in case McCann and Others v. The United Kingdom, application no. 18984/91

[19] ECHR judgment in case McKerr v. The United Kingdom, application no. 28883/95

[20] ECHR judgment in case Andronicou and Constantinou v. Cyprus application no. 86/1996/705/897

[21] ECHR judgment in case Giuliani and Gaggio v. Italy application no. 23458/02 